\title{
Metalloform-Selective Inhibitors of E. coli Methionine Aminopeptidase and X-ray Structure of a Mn(II)-Form Enzyme Complexed with an Inhibitor
}

\author{
Qi-Zhuang Ye, ${ }^{*},{ }^{\dagger}$ Sheng-Xue Xie, ${ }^{\dagger}$ Min Huang, ${ }^{\dagger}$ Wei-Jun Huang, ${ }^{\ddagger}$ Jing-Ping $\mathrm{Lu}^{\dagger}$ and Ze-Qiang $\mathrm{Ma}^{\dagger}$ \\ ${ }^{\dagger}$ The High Throughput Screening Laboratory and the Protein Structure Laboratory, University of Kansas, Lawrence, \\ Kansas 66045 \\ RECEIVED DATE (automatically inserted by publisher); E-mail: qye@ku.edu
}

\section{Supporting materials}

\section{Compound characterization}

The compounds 1-8 were purchased from ChemBridge (San Diego, CA) as solids. Their identity and purity were confirmed by NMR and mass spectroscopy. Proton and carbon NMR spectra were recorded on a Bruker Avance $500 \mathrm{MHz}$ spectrometer.

$\mathbf{N}^{\mathbf{1}}$-cyclopentyl-N $\mathbf{N}^{\mathbf{2}}$-(thiazol-2-yl)oxalamide (1). ${ }^{13} \mathrm{C} \quad \mathrm{NMR}$ $\left(\mathrm{CDCl}_{3}\right): \delta$ 23.6, 32.8, 51.8, 114.7, 137.3, 157.1, 157.7. HRMS (FAB) $m / e$ calcd for $\mathrm{C}_{10} \mathrm{H}_{14} \mathrm{~N}_{3} \mathrm{O}_{2} \mathrm{~S}(\mathrm{M}+\mathrm{H})^{+}:$240.0807, found 240.0803.

$\mathbf{N}^{\mathbf{1}}$-isobutyl-N $\mathbf{N}^{\mathbf{2}}$-(thiazol-2-yl)oxalamide $\quad$ (2). ${ }^{13} \mathrm{C} \quad \mathrm{NMR}$ $\left(\mathrm{CDCl}_{3}\right): \delta 19.9,20.1,28.4,47.2,114.7,137.9,157.0,157.7$, 157.9. HRMS (FAB) m/e calcd for $\mathrm{C}_{9} \mathrm{H}_{14} \mathrm{~N}_{3} \mathrm{O}_{2} \mathrm{~S}(\mathrm{M}+\mathrm{H})^{+}$: 228.0807 , found 228.0718 .

$\mathbf{N}^{\mathbf{1}}$-(pyridin-2-ylmethyl)- $\mathbf{N}^{\mathbf{2}}$-(thiazol-2-yl)oxalamide $(3) .{ }^{13} \mathrm{C}$ $\operatorname{NMR}\left(\mathrm{CDCl}_{3}\right): \delta 42.7,115.1,122.2,138.7,150.1,156.1,156.8$, 158.4. HRMS (FAB) m/e calcd for $\mathrm{C}_{11} \mathrm{H}_{11} \mathrm{~N}_{4} \mathrm{O}_{2} \mathrm{~S}(\mathrm{M}+\mathrm{H})^{+}$: 263.0603, found 263.0592 .

5-(2-chlorophenyl)furan-2-carboxylic acid (4). ${ }^{13} \mathrm{C}$ NMR $\left(\mathrm{CDCl}_{3}\right): \delta 112.8,121.4,127.1,127.8,129.0,129.8,130.8,131.2$, 142.3, 154.6, 160.9. HRMS (FAB) $m / e$ calcd for $\mathrm{C}_{11} \mathrm{H}_{8} \mathrm{ClO}_{3}(\mathrm{M}$ $+\mathrm{H})^{+}: 223.0162$, found 223.0145 .

5-(2-chloro-3-methylphenyl)furan-2-carboxylic acid $(5) .{ }^{13} \mathrm{C}$ $\operatorname{NMR}\left(\mathrm{CDCl}_{3}\right): \delta 17.8,111.5,121.2,126.8,127.3,130.1,130.9$, 134.0, 135.8, 142.7, 157.5, 161.5. HRMS (FAB) m/e calcd for $\mathrm{C}_{12} \mathrm{H}_{10} \mathrm{ClO}_{3}(\mathrm{M}+\mathrm{H})^{+}: 237.0318$, found 237.0297.

5-[2-(trifluoromethyl)phenyl]furan-2-carboxylic acid (6). ${ }^{13} \mathrm{C} \mathrm{NMR}\left(\mathrm{CDCl}_{3}\right): \delta 112.2,121.3,122.5,124.7,126.7,128.1$, 129.2, 130.7, 131.9, 143.4, 154.8, 161.5. HRMS (FAB) m/e calcd for $\mathrm{C}_{12} \mathrm{H}_{7} \mathrm{~F}_{3} \mathrm{NaO}_{3}(\mathrm{M}+\mathrm{Na})^{+}: 279.0245$, found 279.0240 .

5-(2-fluorophenyl)furan-2-carboxylic acid (7). ${ }^{13} \mathrm{C}$ NMR $\left(\mathrm{CDCl}_{3}\right): \delta 112.0,116.1,117.5,122.1,124.5,127.1,130.4,142.3$, 152.7, 158.4, 160.4, 162.3. HRMS (FAB) m/e calcd for $\mathrm{C}_{11} \mathrm{H}_{8} \mathrm{FO}_{3}$ $(\mathrm{M}+\mathrm{H})^{+}: 207.0457$, found 207.0428 .

5-(3-chlorophenyl)furan-2-carboxylic acid (8). ${ }^{13} \mathrm{C}$ NMR $\left(\mathrm{CDCl}_{3}\right): \delta 108.0,121.9,123.0,124.9,129.2,130.1,130.8,135.0$, 143.0, 156.9, 161.9. HRMS (FAB) $m / e$ calcd for $\mathrm{C}_{11} \mathrm{H}_{8} \mathrm{ClO}_{3}(\mathrm{M}+$ $\mathrm{H})^{+}: 223.0162$, found 223.0142 .

\section{Crystallization condition}

The recombinant E. coli methionine aminopeptidase (EcMetAP1) was prepared as reported previously. ${ }^{1}$ The purified protein was exchanged to a MOPS buffer $(10 \mathrm{mM}, \mathrm{pH} 7.0)$ by a desalting column. The apo-enzyme was concentrated to $12 \mathrm{mg} / \mathrm{ml}$ (0.4 mM), and $\mathrm{MnCl}_{2}(2 \mathrm{mM})$ and the inhibitor (4, $\left.4 \mathrm{mM}\right)$ were added to the protein solution prior to crystallization experiments. Crystals were grown at room temperature with the hanging drop vapor diffusion method. The protein solution $(3 \mu 1)$ was mixed with equal volume of the reservoir solution, which contained $15 \%$ PEG 8000 and 0.1 M HEPES (pH 7.5).

Data collection and structure refinement

The enzyme was crystallized in space group $\mathrm{P} 2{ }_{1}, \mathrm{a}=37.6 \AA \mathrm{,}, \mathrm{b}$ $=60.3 \AA, \mathrm{c}=49.7 \AA, \beta=104.79^{\circ}$. A dataset to $1.52 \AA$ was collected on a Raxis IV imaging plate. 180 degrees were collected on images of 0.5 degree. The data was processed with the XDS package. $^{2}$ Structure solution was achieved using the CCP4 suite. ${ }^{3}$ The structure was solved with program AMORE using an available EcMetAP1 structure at $1.9 \AA$ resolution (PDB access code 2MAT) as search model.

Model building was carried out using $\mathrm{O},{ }^{4}$ and crystallographic refinement was performed with $\mathrm{CNS}^{5}$ The refinement was monitored with free $\mathrm{R}$ factor throughout the whole refinement process, with $5 \%$ of the total number of reflections set aside. The initial crystallographic $\mathrm{R}$ factor was $35 \%$, and the refinement process included simulated annealing to a starting temperature of 4000 degrees, positional refinement, individual B factor refinement, and addition of water molecules. The free $\mathrm{R}$ factor continued to drop as the refinement progressed. After several more rounds of the above refinements except for the simulated annealing, we concluded the refinement. The resulted electron density map showed clear densities for most of the atoms except for a few side chains at the molecular surface.

Data collection statistics: resolution range 50-1.52 $\AA$, number of reflections (unique) 109893 (32393), completeness (last shell) $97.7 \%(92.5 \%), R_{\text {sym }}$ (last shell) $5.0 \%(16.3 \%)$, and $\mathrm{I} / \sigma$ (last shell) $16.11(5.1)$.

Refinement statistics: resolution range 50-1.52 $\AA$, number of reflection (test) 30772 (1620), $R_{\text {cryst }} 21.9 \%, R_{\text {free }} 25.2 \%$, rmsd bond length $0.005 \AA$, rmsd bond angles $1.366^{\circ}$, number of protein atoms (average B) 2035 (15.8), number of inhibitor atoms (average B) 15 (12.3), number of metal ions (average B) 3 (10.4), and number of water atoms (average B) 182 (25.6).

Overall structure of the complex is shown in Fig. S1, and electron density of the inhibitor and $\mathrm{Mn}(\mathrm{II})$ ions are shown in Fig. S2. The Figure 1A, 1B and S1 were generated using PyMOL. ${ }^{6}$

References

(1) Li, J. Y.; Chen, L. L.; Cui, Y. M.; Luo, Q. L.; Li, J.; Nan, F. J.; Ye, Q. Z. Biochem. Biophys. Res. Commun. 2003, 307, 172-179.

(2) Kabsch, W. J. Appl. Cryst. 1993, 26, 795-800.

(3) Collaborative Computational Project, number 4 Acta Crystallogr. D. 1994, 50, 760-763.

(4) Jones, T. A.; Zhou, J. Y.; Cowan, S. W.; Kjelgaard, M. Acta Crystallogr. A. 1991, 47, 110-119.

(5) Brunger, A. T.; Adams, P. D.; Clore, G. M.; DeLano, W. L.; Gros, P.; Grosse-Kunstleve, R. W.; Jiang, J. S.; Kuszewski, J.; Nilges, M.; Pannu, N. S.; Read, R. J.; Rice, L. M.; Simonson, T.; Warren, G. L. Acta Crystallogr D. 1998, 54, 905-921.

(6) DeLano, W. L. The PyMOL Molecular Graphics System, 2002 DeLano Scientific, San Carlos, CA, USA. 


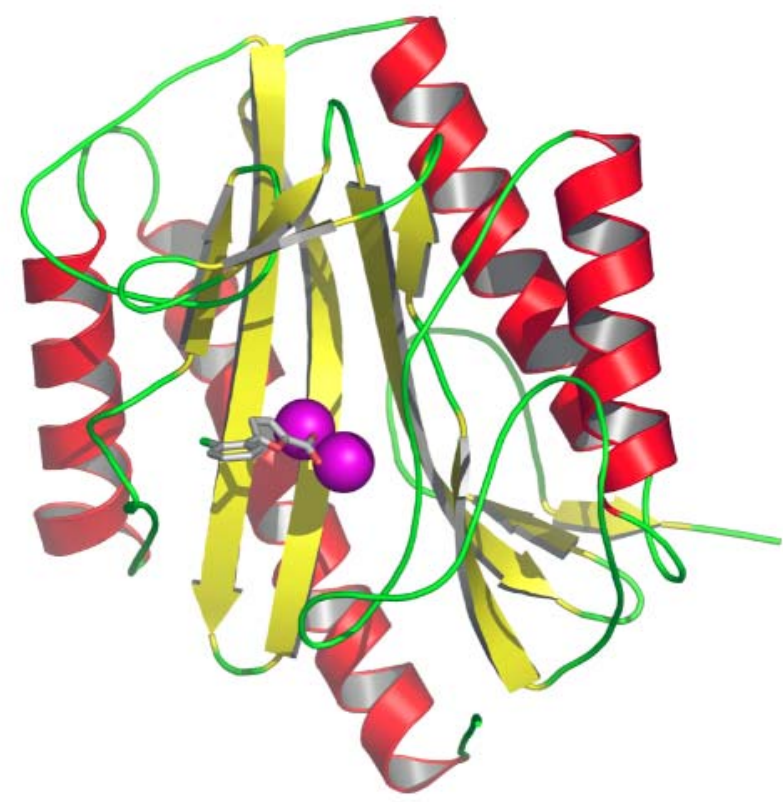

Figure S1. Ribbon drawing showing the overall structure of the complex between the E. coli MetAP and the inhibitor $4 . \mathrm{Mn}(\mathrm{II})$ ions are shown as magenta spheres and the inhibitor is shown as sticks (carbon grey, oxygen red, nitrogen blue, and chlorine green).

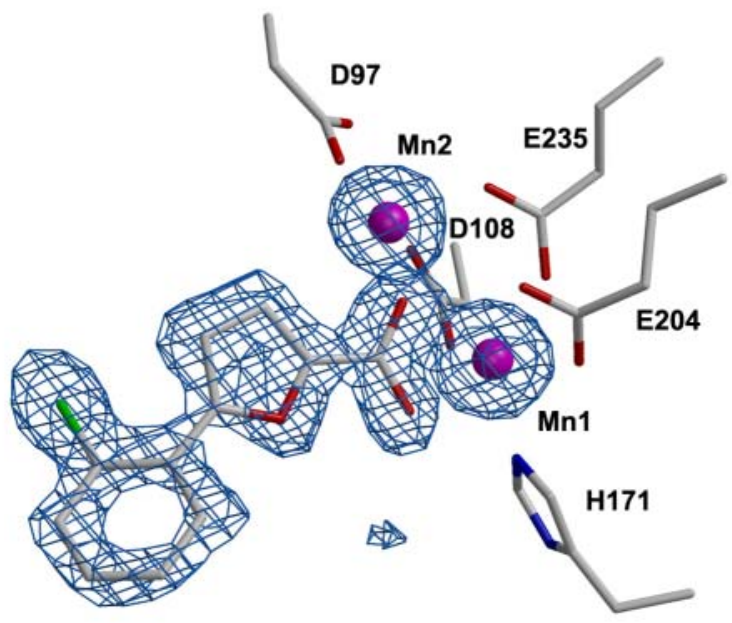

Figure S2. Electronic density for the inhibitor and the metal ions (contoured at $3 \sigma$ ). The inhibitor and metals were omitted from the refined model during map calculation. 


\section{${ }^{1} \mathrm{H}$ and ${ }^{13} \mathrm{C}$ NMR Spectra}
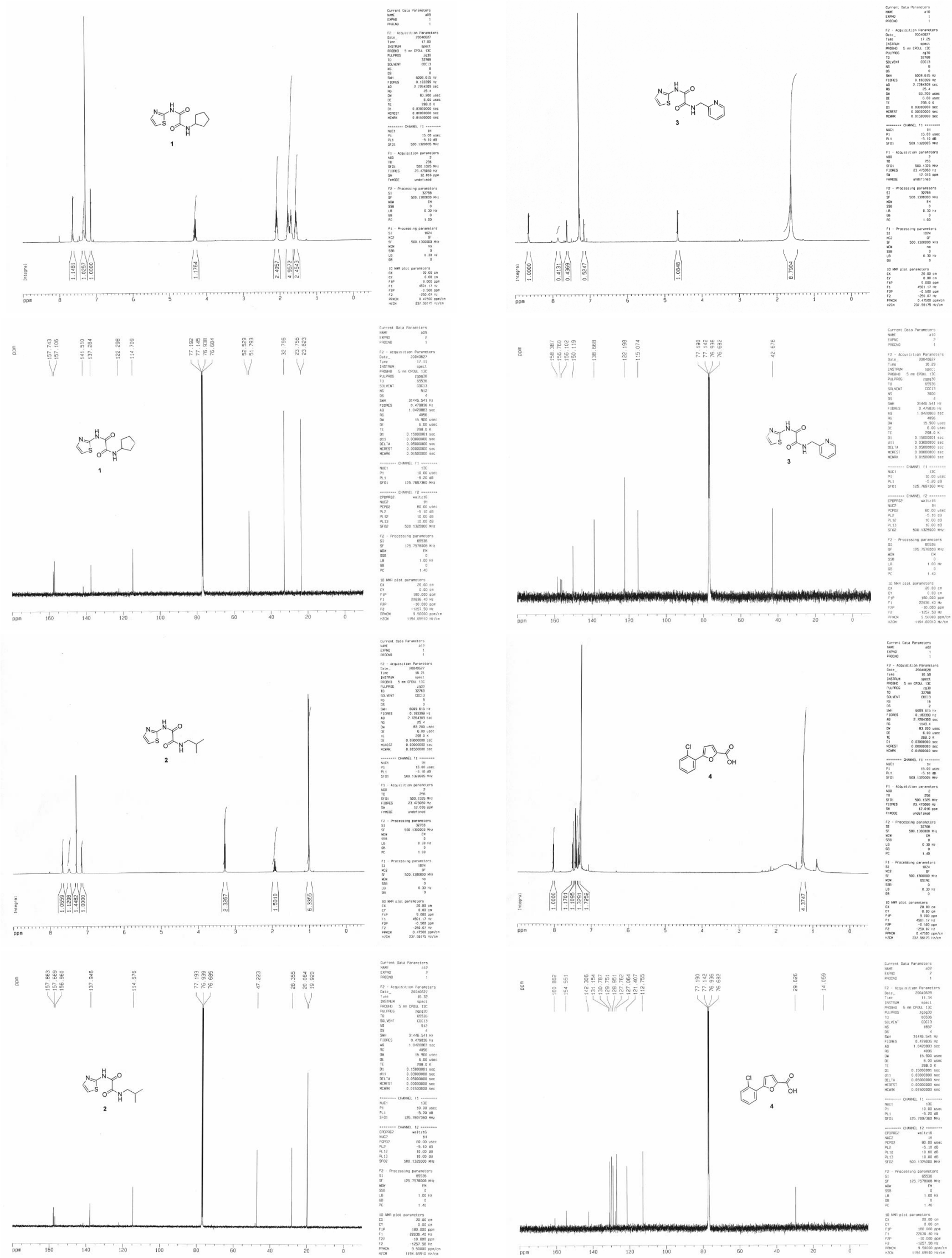

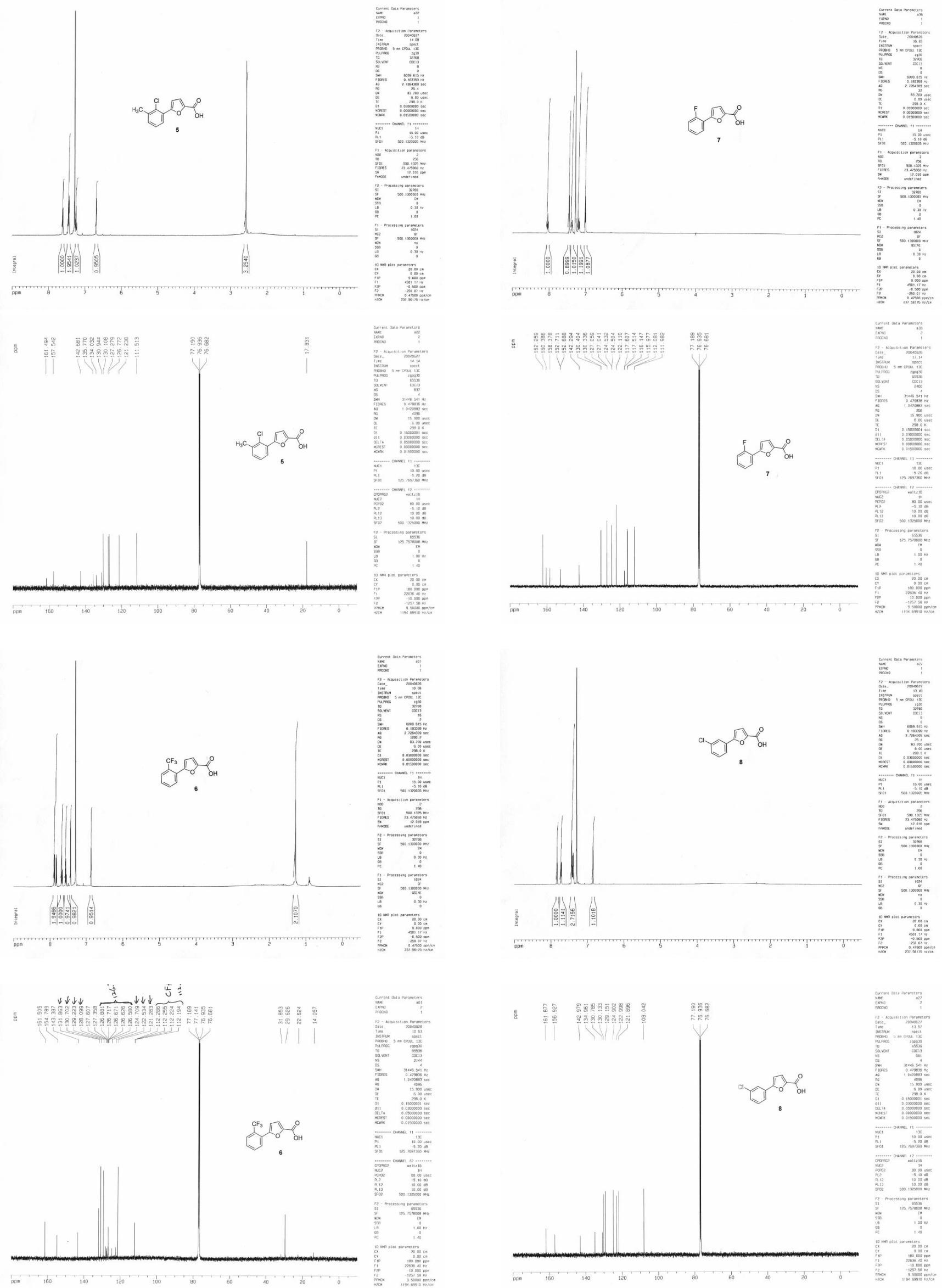
